\title{
New Refractories Made from Reused Silicon Carbide
}

\author{
使用済み炭化ケイ素を用いる新規耐火物 \\ Emad Mohamed M. EWAIS, Mohamed I. AL-WAKEEL, * Nagy KHALIL** and Yasser M. Z. AHMED \\ Refractory \& Ceramic Materials Lab., Central Metallurgical Research and Development Institute (CMRDI), \\ P.O. Box 87, Helwan, 11421 Cairo, Egypt \\ ${ }^{*}$ Geology Department, Faculty of Science, Ain Shams University, Cairo, Egypt \\ **National Research Centre, Dokki, Giza, Egypt
}

\begin{abstract}
Reuse/recycling of silicate bonded silicon carbide plates materials after removal from ceramic industrial service was evaluated for ceramic and steel industry. Experimental batches from spent slabs with different contents of bauxite and silica fume were prepared and fired up to $1400^{\circ} \mathrm{C}$. Their densification properties in terms of bulk density and apparent porosity were measured and correlated with objecting properties. Mineralogy and microstructure of the sintered batches were studied and correlated with the ratio of their cold crushing strengths after 30 subsequent thermal shock cycles and before subjecting the batches to the thermal shock. The formation of mullite, replacement of silicon carbide by mullite and formation of pseudo silicon carbide, tight structure and well distribution of silicon carbide were recorded. The ratio of strengths after and before shock enhanced with increasing mullite content up to about $40 \%$. All batches gave a superior thermal shock resistance where no spalling was observed up to 30 cycles of heating up to $950^{\circ} \mathrm{C}$ and water quenching.
\end{abstract}

[Received July 25, 2003; Accepted May 26, 2004]

Key-words : Recycling, Silicon carbide, In-situ mullite, Microstructure, Technological properties, Metallurgical and ceramic industries

\section{Introduction}

SiC-based materials are attracting more and more attention within research activities in advanced refractories across the world. This is due to its outstanding properties, which include mechanical strength, wear resistance, heat conductivity, and thermal shock resistance. These types of specification offer these materials to be good candidates for applications involving severe working environment and different fields of industries. On the other hand, aluminosilicate in particularly mullite $\left(3 \mathrm{Al}_{2} \mathrm{O}_{3} \cdot 2 \mathrm{SiO}_{2}\right)$ has long been recognized as an outstanding ceramic material for high-temperature engineering applications because of its good strength at high temperature, creep resistance, low thermal expansion coefficient and chemical stability. ${ }^{1)}$

In ceramic industry, silicon carbide based materials, and cordierite-mullite have been used as saggers. ${ }^{2), 3)}$ This is due to their high thermal conductivity, high temperature services and good resistance to thermal shock. The types of refractories basic on $\mathrm{SiC}$ have average bulk density $2.4 \mathrm{~g} / \mathrm{cm}^{3}$, apparent porosity $14-22 \%$ and service temperature $1400^{\circ} \mathrm{C} .{ }^{3)}$ The defect of $\mathrm{SiC}$ is its tendency for volume increase when the service temperature exceeds $1000^{\circ} \mathrm{C}$. On the other hand, in metallurgical industries specially in blast furnace $(\mathrm{BF})$, alumino silicate refractory bricks with different contents of alumina are the mainly materials used for lining most of all areas of blast furnace except its hearth. ${ }^{4)}$ However, high thermal conductivity, abrasion resistance and thermal shock resistance are considered important properties required for lining blast furnace cooling parts. Therefore, using of SiC-based aluminosilicate refractories enhanced the campaign life of the $\mathrm{BF}$ and consequently, has been engineered into the overall blast furnace system through proper cooling practice, proper resistance to attack and wear, and proper selection of conductive ramming materials. ${ }^{5-12)}$

It is well known that the oxidizing atmospheres has been considered one of the problems that negatively affects on the efficiency of the SiC performance. Therefore, the successful formation or manufacture of dense, strong adherent coat as barrier for SiC-based ceramics will prevent the oxidation of $\mathrm{SiC}$ grains. Some important characteristics, such as the lower thermal expansion coefficient, chemical compatibility and phase stability, of the barrier coat for the formed phase should be taken in the consideration. As reported, the mullite phase has been had these characteristics. ${ }^{13)}$ Furthermore, the physical and mechanical properties of the SiC-based ceramics can be enhanced and developed if the mullite is the representative constitutes of the matrix. ${ }^{14)}$ Therefore, the preparation of objects constitute from two valuable phases; $\mathrm{SiC}$ and mullite as ceramic matrix, will expected to have excellent refractory properties for the metallurgical and ceramic industries.

A decision to use silicon carbide in ceramic industry and blast furnace is certainly supported in the majority of cases from the economical and technical point of view but often purely financially and investment considerations turn the scales. On the other hand, a considerable quantity of spent silicate bonded silicon carbide (carborundum) plates are generated annually by Egyptian ceramic companies. Most of spent refractory is disposed of in landfill and contaminates the virgin raw materials. The successful reuse/recycling of these silicon carbide plates after removal from ceramic industrial service will be benefit from the economic point of view. Thus, this work aims to evaluate the feasibility of recycle the silicon carbide plates into new refractory types and reuse it for blast furnace stack and in a manner similar to its original application.

\section{Materials and experimental procedure}

\subsection{Materials and additives}

The industrial waste of silicate bonded silicon carbide plates from one of Egyptian ceramic industry consumer was chosen for characterization and recycling studies. Representative sample was collected and crushed into $-3 \mathrm{~mm}$. Chemical analysis of silicon carbide slab waste and additives (silica fume waste and bauxite) were given in Table 1. X-ray diffrac- 
Table 1. Average Chemical Analysis of the Starting Raw Materials

\begin{tabular}{|l|c|c|c|}
\hline $\begin{array}{c}\text { Chemical } \\
\text { composition }\end{array}$ & $\begin{array}{c}\text { Silicon carbide } \\
\text { waste, } \\
\text { Mass \% }\end{array}$ & $\begin{array}{c}\text { Bauxite, } \\
\text { Mass \% }\end{array}$ & $\begin{array}{c}\text { Silica fume, } \\
\text { Mass \% }\end{array}$ \\
\hline $\mathrm{SiC}$ & 86.9 & - & - \\
$\mathrm{SiO}_{2}$ & 8.8 & 6.17 & 94.86 \\
$\mathrm{Al}_{2} \mathrm{O}_{3}$ & 3.4 & 87.98 & 0.15 \\
$\mathrm{Fe}_{2} \mathrm{O}_{3}$ & 0.9 & 1.75 & 0.91 \\
$\mathrm{TiO}_{2}$ & - & 3.52 & - \\
$\mathrm{CaO}$ & - & 0.19 & 0.26 \\
$\mathrm{MgO}$ & - & - & 0.58 \\
$\mathrm{~L} . \mathrm{O} . \mathrm{I}$ & - & 0.26 & 2.27 \\
\hline Total & 100 & 99.87 & 99.03 \\
\hline
\end{tabular}

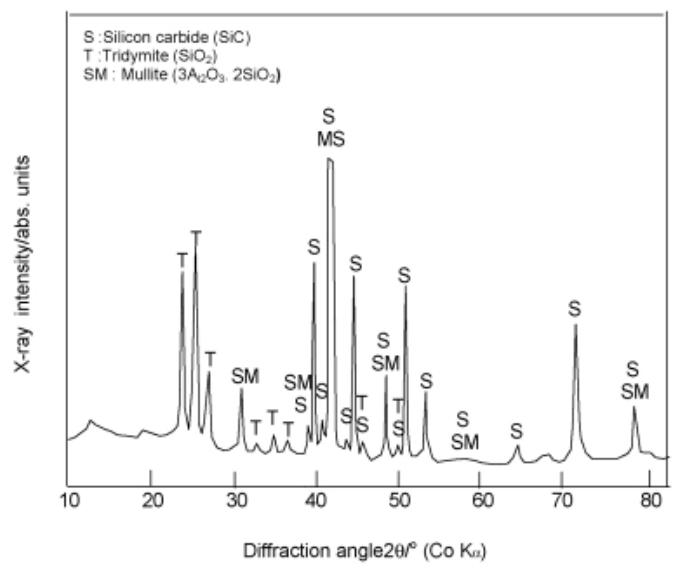

Fig. 1. X-ray diffraction pattern of silicon carbide slab waste.

tion pattern of the $\mathrm{SiC}$ waste was shown in Fig. 1. It consists mainly of $\mathrm{SiC}$ and small amount of mullite $\left(3 \mathrm{Al}_{2} \mathrm{O}_{3} \cdot 2 \mathrm{SiO}_{2}\right)$ and silica $\left(\mathrm{SiO}_{2}\right)$ in the form of tridymite. Bauxite is used as a source of alumina.

\subsection{Experimental procedure}

In this work, mixtures from bauxite $(-0.1 \mathrm{~mm})$ and silica fumes were prepared aiming to formation of mullite. This mixture was added to the silicon carbide crushed plates $(-2$ $\mathrm{mm})$ in a percentage ranges from $10-50$ mass $\%$ with intervals 10 mass $\%$ as given in Table 2. 5.3 mass $\%$ of mono-aluminum phosphate was added to the mixture to enhance the green strength and to decrease the oxidation resistance of silicon carbide. Sample briquettes of $2.5 \mathrm{~cm}$ diameter were molded under pressure of $800 \mathrm{~kg} / \mathrm{cm}^{2}$ using a semi-dry pressing process. After drying for $24 \mathrm{~h}$ at $110^{\circ} \mathrm{C}$, the green density of the batches were $2-2.2 \mathrm{~g} / \mathrm{cm}^{3}$ as given in Table 3. The formed briquettes were fired at temperature range between 1250$1400^{\circ} \mathrm{C}$ for one hour at each peak temperature in an electric furnace. The samples were allowed to cool gradually overnight. Densification parameter in terms of bulk density and apparent porosity of fired samples were determined according to JIS R 2205. To confirm the mullite formation, X-ray diffraction analysis was performed by Philips diffractometer, using Ni-filter and Co radiation target.

Mechanical strength in term of cold crushing strength (CCS) of the fired samples was measured using Control Hydraulic Press model (Controls (CE), Datamatic, Italy). The cold crushing strength was determined by applying a load at uniform rate to the central part of both side faces with respect to the position of specimen as molded, using bearing plates.

The fired samples were heated up to $950^{\circ} \mathrm{C}$ and then quen-
Table 2. Batches Compositions of Recycled Waste Slab of SiC

\begin{tabular}{|c|c|c|c|}
\hline Batch No. & $\begin{array}{c}\text { SiC waste } \\
(\mathbf{0 - 2} \mathbf{~ m m}), \\
\%\end{array}$ & $\begin{array}{c}\text { Bauxite } \\
\mathbf{( - \mathbf { 0 . 1 }} \mathbf{~ m m}), \\
\%\end{array}$ & $\begin{array}{c}\text { Silica fume } \\
\mathbf{( - \mathbf { 0 . 1 }} \mathbf{~ m m}), \\
\%\end{array}$ \\
\hline 1 & 90 & 8 & 2 \\
2 & 80 & 16 & 4 \\
3 & 70 & 24 & 6 \\
4 & 60 & 32 & 8 \\
5 & 50 & 40 & 10 \\
\hline
\end{tabular}

Table 3. Green Density of the Batches Compositions of Recycled Waste Slab of SiC

\begin{tabular}{|c|c|c|c|c|}
\hline Batch No. & \multicolumn{3}{|c|}{$\begin{array}{c}\text { Composition, } \\
\text { \% }\end{array}$} & $\begin{array}{c}\text { Green } \\
\text { density, } \\
\text { g/cm }\end{array}$ \\
\cline { 2 - 4 } & $\begin{array}{c}\text { SiC waste } \\
\text { (0-2 } \mathbf{~ m m )}\end{array}$ & $\begin{array}{c}\text { Bauxite } \\
\mathbf{( - \mathbf { 0 . 1 }} \mathbf{~ m m})\end{array}$ & $\begin{array}{c}\text { Silica fume } \\
\mathbf{( - \mathbf { 0 . 1 }} \mathbf{~ m m})\end{array}$ & \\
\hline 1 & 90 & 8 & 2 & 2.00 \\
2 & 80 & 16 & 4 & 2.05 \\
3 & 70 & 24 & 6 & 2.11 \\
4 & 60 & 32 & 8 & 2.16 \\
5 & 50 & 40 & 10 & 2.20 \\
\hline
\end{tabular}

ched into $20^{\circ} \mathrm{C}$ water. After 30 cycles of thermal shock, cold crushing strength of the samples were measured and taken as a criteria for thermal shock resistance.

The microstructures of the prepared briquettes were studied by different techniques. Optical polarizing microscope (OPM), was used for studying thin sections prepared from the fired samples. The polished and rough surfaces of the specimens were investigated with reflected light microscope (BM), and Scanning Electron Microscope (SEM), Model Jeol; JSM-6400. Such studies of investigation are conducted to identify the sample textures, and phases and their distribution to help in understanding the changes in the technological properties of the specimens with the different contents of bauxite/silica fume.

\section{Results and discussion}

\subsection{Mineralogical structure}

The X-ray diffraction pattern of the prepared fired batches at $1400^{\circ} \mathrm{C}$ as shown in Fig. 2 reveal that the presence of two major phases i.e. mullite $\left(3 \mathrm{Al}_{2} \mathrm{O}_{3} \cdot \mathrm{SiO}_{2}\right)$ and $\mathrm{SiC}$ phases, in addition to tridymite $\left(\mathrm{SiO}_{2}\right)$ phase and unknown peaks. Alumina was not observed. This indicates that mullite was formed by the reaction of bauxite and silica fume, in addition of the excess silicate bond of the $\mathrm{SiC}$ waste. ${ }^{15)}$ It was noted that the concentration of the mullite phase increases with the increase of the amount of added bauxite-silica fume mixture of constant ratio $(4: 1)$.

\subsection{Microstructures}

Generally, the microstructures of the studied batches reveal that relatively coarse, massive silicon carbide and mullite crystals embedded in a matrix of micro-crystalline and fibrous materials as shown in Figs. 3-5. The fibrous materials is considered to be mullite.

The formed mullite is buff to buff gray in color and has a glassy luster. The mineral is colorless in thin section, with strong relief and distinct cleavage, Fig. 3. Its content increases from batch No. 1 to batch No. 5 due to increase the additions of bauxite and silica fume. It appeared in the microcrystalline form constituting the groundmass (matrix), and a crystalline form. The crystalline is found in prismatic, rod and subhedral crystals. Such crystals are varied in size and its crystallinity 


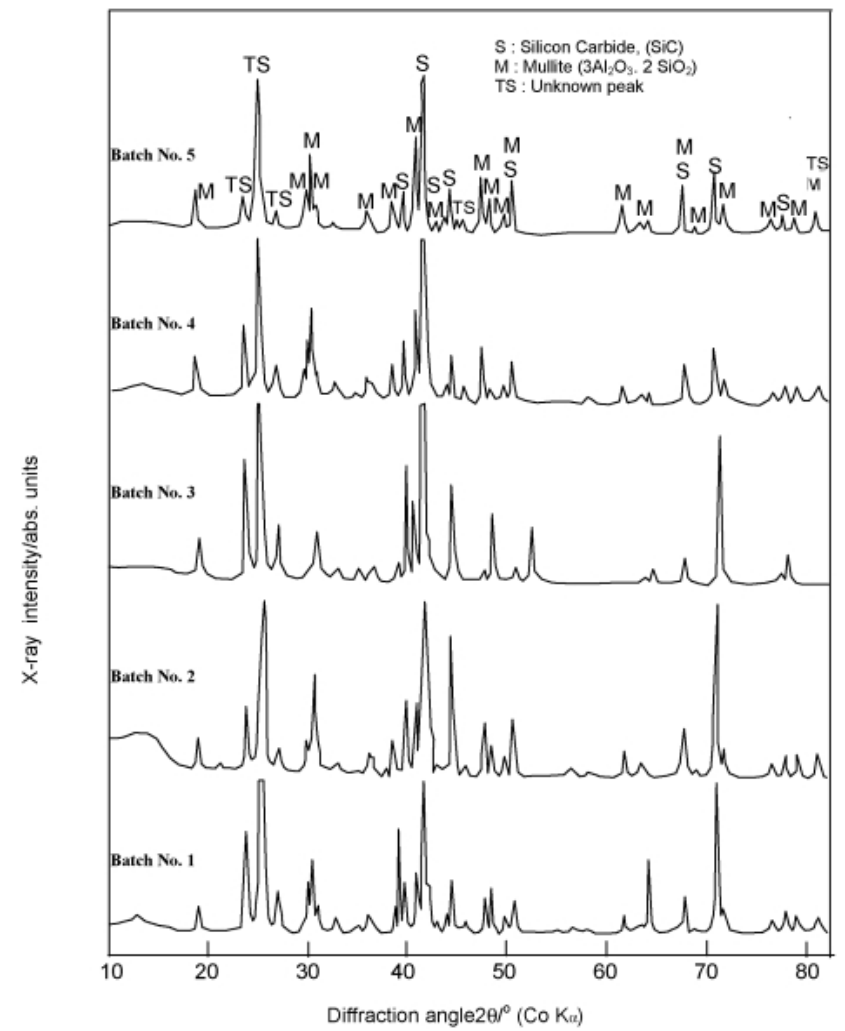

Fig. 2. X-ray diffraction patterns of the fired samples.

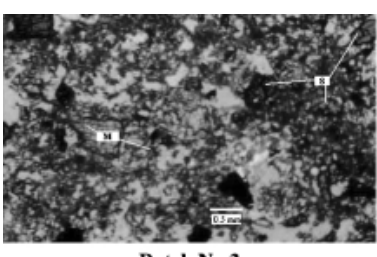

Batch No.3
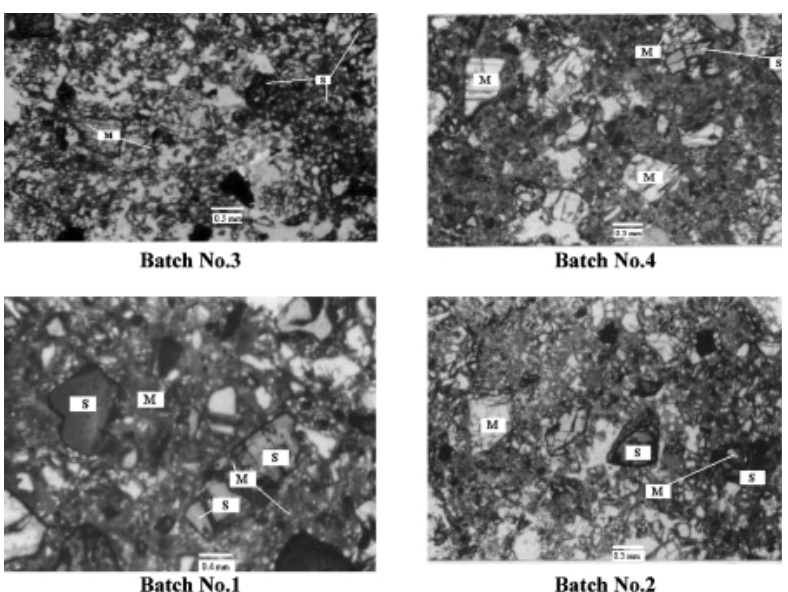

Batch No.2

Fig. 3. Thin section photomicrographs of the fired samples (plane polarized light) $\mathrm{S}=$ Silicon carbide $(\mathrm{SiC}), \mathrm{M}=$ Mullite $\left(3 \mathrm{Al}_{2} \mathrm{O}_{3}\right.$. $2 \mathrm{SiO}_{2}$ ).

improves from batch 1 (reaches up to $0.74 \mathrm{~mm}$ ) to batch 5 (reaches up to $1.19 \mathrm{~mm}$ ). Crystals with fractures are occasionally recorded. The fibrous materials has either a texture looked like a kind of whisker around the pores, or a dendritic structure of locked grains, Fig. 4 (Batch Nos. $1 \& 3$ ). The fibrous materials aggregates contain micro-pores. This kind of pores increases with increasing mullite content.

The silicon carbide mineral is represented by coarse to fine crystals $(0.07$ to $2.04 \mathrm{~mm})$ and dark grey to black in color, and have metallic luster and radial fracture. In thin section, Fig. 3, silicon carbide crystals are blue to pale blue in color, and have distinct parting and strong relief. They are subhedral

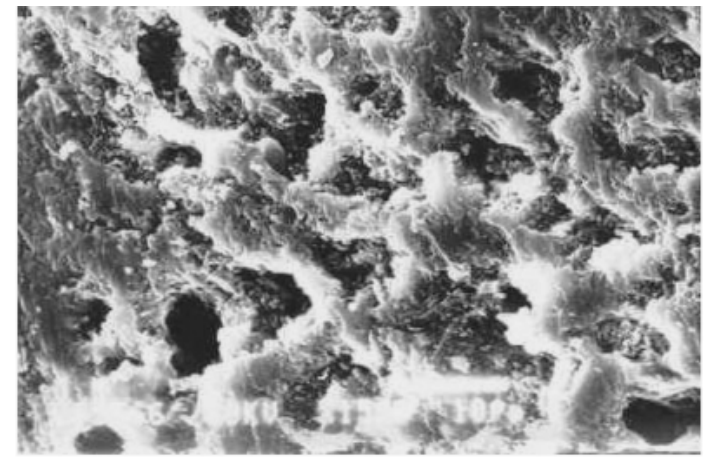

Batch No. 3

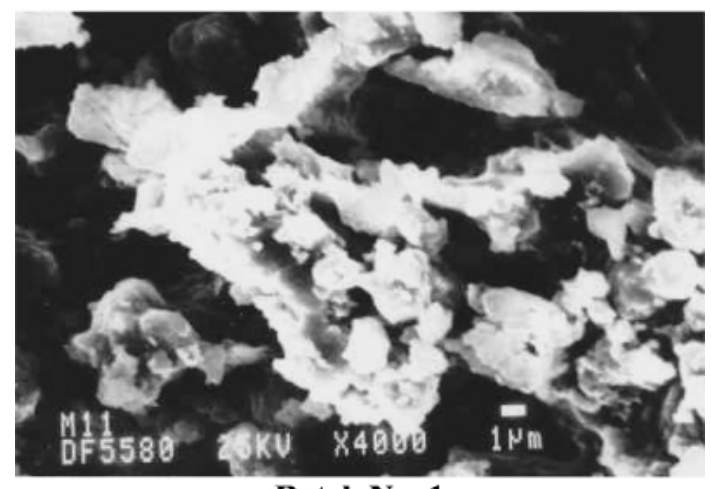

Batch No. 1

Fig. 4. SEM photomicrographs of the fired samples.

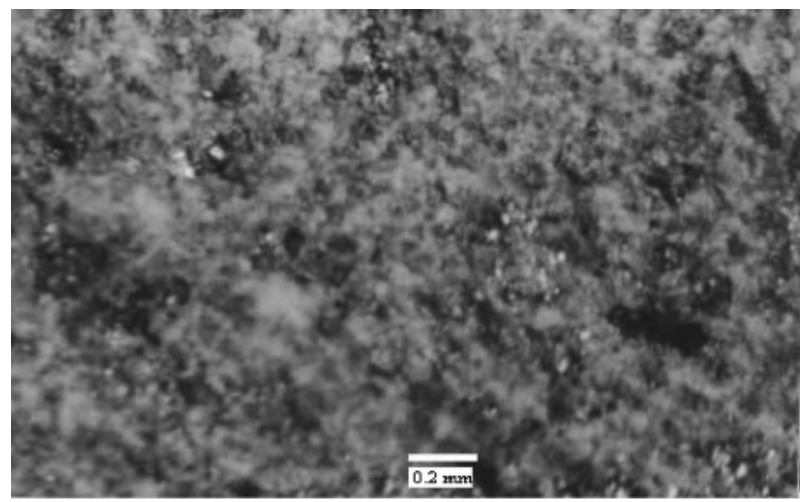

Batch No. 4

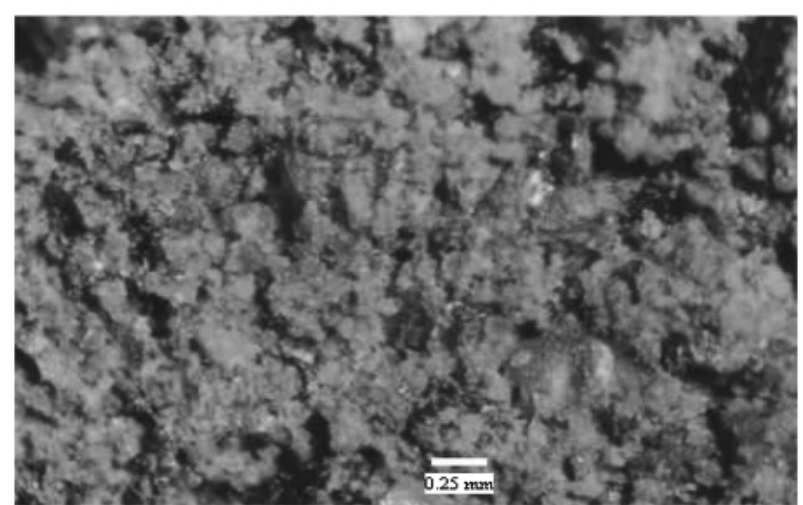

Batch No. 1

Fig. 5. Photomicrographs of the fired samples. 
to anhedral, and occasionally prismatic crystals. Its content decreases from batch No. 1 to batch No. 5. Generally, the grain size reduces from batch No. 1 (maximum size; $2.04 \mathrm{~mm}$ ) to batch No. 5 (maximum size; $1.11 \mathrm{~mm}$ ), and also the crystal shape changes from euhedral to subhedral (batch No. 1) to anhedral or angular (batch No. 5). In the last two samples, the silicon carbide is fine to very fine and well distributed.

The petrographic investigation reveals that the silicon carbide waste grains are replaced with mullite. The evidences of replacement are confirmed by the presence of mullite inside the silicon carbide crystals especially in the fractures on the border, Fig. 3 (Batch Nos. $1 \& 2$ ), and the remnants of silicon carbide waste grains in between mullite crystals. In addition, the presence of some borders of silicon carbide are coated with mullite. Moreover, the preservation of silicon carbide crystal form and parting in the new mullite crystals, Fig. 3 (Batch Nos. 2, 3 and 4), and forming pseudo-silicon carbide waste grain (mullite presents in the crystal form of silicon carbide). This process was conducted through the partings and borders causing fragmentation of the silicon carbide waste grains, and producing angular or anhedral and well distributed crystals. So, with the addition of bauxite and silica fume, the maximum crystal size of silicon carbide decreased from 2.04 to $1.11 \mathrm{~mm}$, meanwhile, large mullite crystals are formed and the size increased from microcrystalline to $1.19 \mathrm{~mm}$.

Accordingly, the pseudo $\mathrm{SiC}$ waste grains (mullite aggregates) formed may be the result of oxidation of silicon carbide. This reaction may be due to the diffusion of the air oxygen through the mullite coat of $\mathrm{SiC}$ leading to the oxidation of $\mathrm{SiC}$ to $\mathrm{SiO}_{2} \cdot{ }^{13)}$ Consequently, alumina easily reacts with $\mathrm{SiO}_{2}$ forming mullite. Further diffusion of the oxygen at high temperature leads to further oxidation of $\mathrm{SiC}$ to $\mathrm{SiO}_{2}$ and reaction with alumina forming mullite. This, in turn, will continue till partial and complete replacement forming pseudo silicon carbide waste grain (mullite).

The packing of the particles in the fired samples changes from open packing (loss structure) in the first batch to well packing in the last batch, Fig. 5. Since, the packing has a good relationship with the apparent porosity and structure, therefore, the open packing is accompanied with high porosity and loss structure, while the well packing accompanied with low porosity and tight structure, consequently, increases in bulk density.

The intergranular contacts between the components (mullite and silicon carbide) become better in the last samples, which consists of $40 \& 50 \%$ of bauxite-silica fume mixture of constant ratio $(4: 1)$ and causing gray coloration of the mullite mineral.

On heating and water quenching of the subsequent thermal shock, the samples have lamination structure parallel to the basal plane arranged from base to top. The laminations include in between elongated or lenticular pores oriented in one direction parallel to the lamination, Fig. 6. This lamination interpreted by the expansion and contraction of the different phases by different rates causing the formation of shrinkage planes. These planes are formed in a direction where the release occurs. Such phenomena were not recorded in the unshocked samples.

\subsection{Technological properties}

The densification parameters in terms of apparent porosity and bulk density of silicon carbide waste at different temperatures as function of different contents of a constant ratio of bauxite/silica fume is shown in Figs. 7 and 8. These figures show that the porosity decreases with increasing the temperature of firing and the amount of added bauxite-silica fume

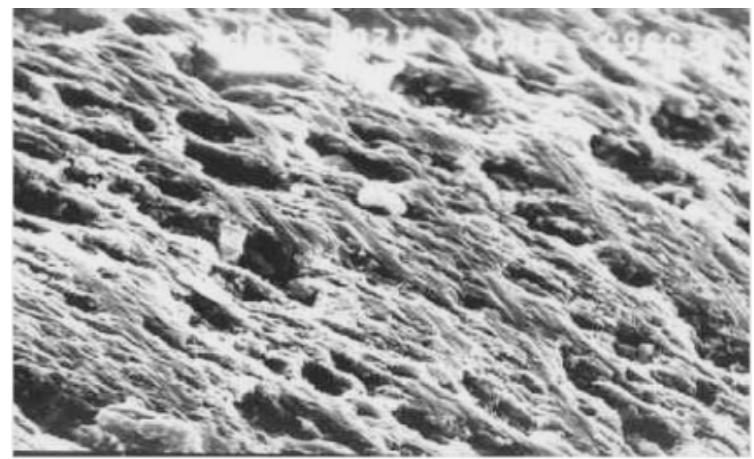

Batch No. 4

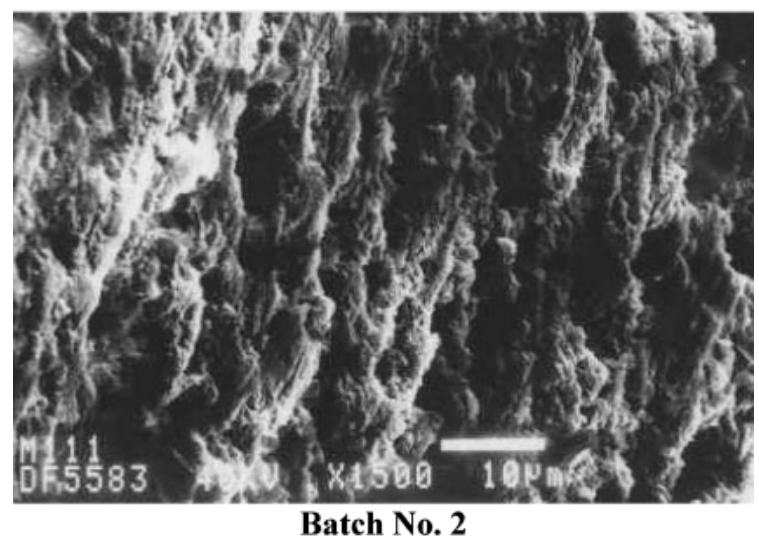

Fig. 6. SEM photomicrographs of the fired samples after the thermal shock test.

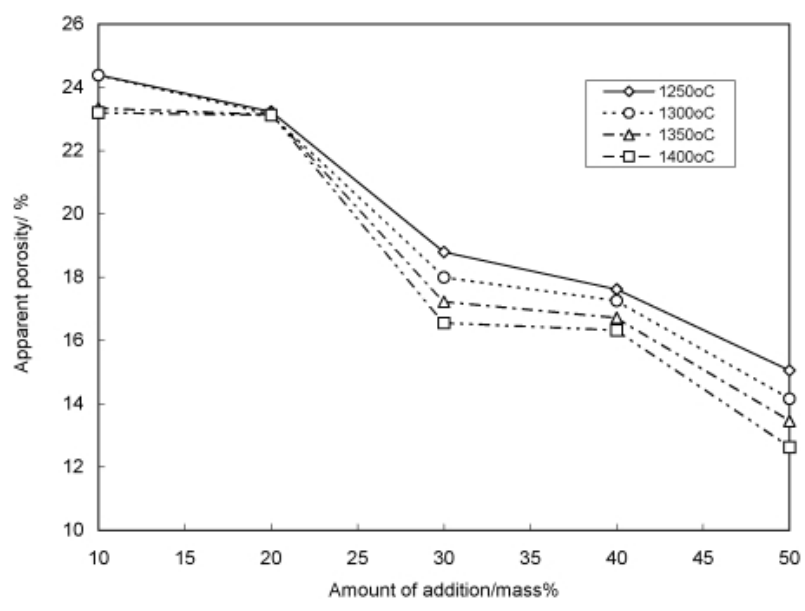

Fig. 7. Aparent porosity of recycled slab waste with different amount of added bauxite-silica fume mixture of constant ratio $(4: 1)$.

mixture of constant ratio $(4: 1)$. However, the bulk density of these batches increases with increasing the temperature of firing and the addition of bauxite and silica fume. It can also be observed that there are remarkable enhancement in the quality of the batches in terms of dense and porosity with addition of $30-50 \%$ from bauxite/silica fume ratio at all studied firing temperatures i.e. bulk density values vary from 2.42 to $2.55 \mathrm{~g} / \mathrm{cm}^{3}$, whereas the porosity varies from $18-12 \%$ at the temperature ranges of 1250 to $1400^{\circ} \mathrm{C}$. In general, the increasing of the bulk density is attributed to the formation of mullite phase, which has relatively higher density $(3.23 \mathrm{~g} /$ 


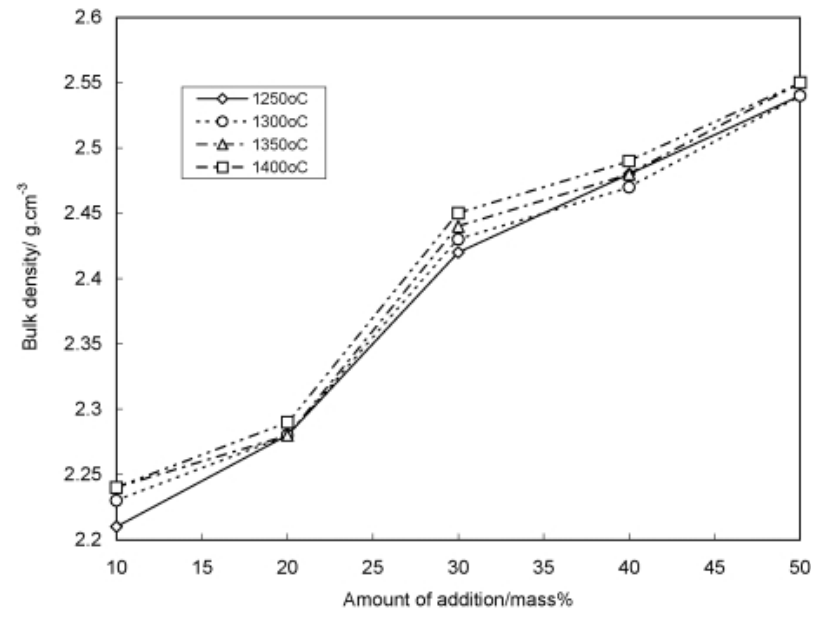

Fig. 8. Bulk density of recycled slab waste with different amount of added bauxite-silica fume mixture of constant ratio $(4: 1)$.

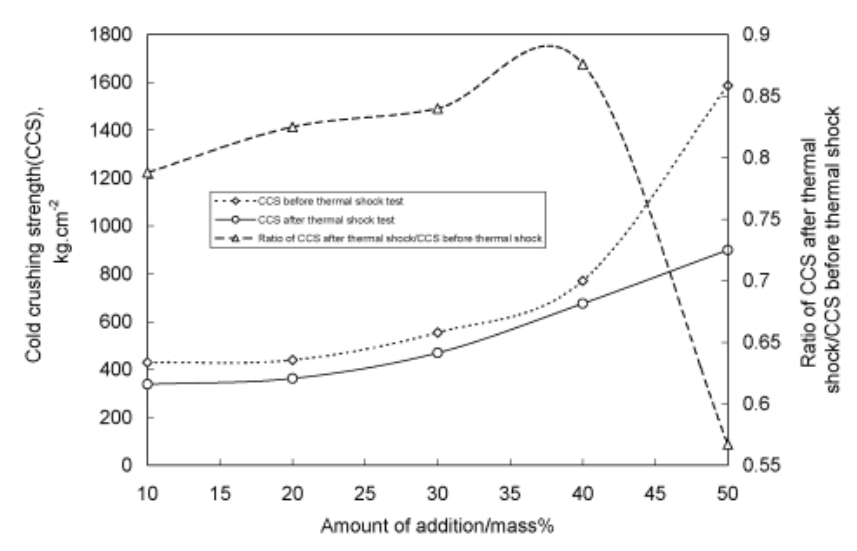

Fig. 9. Cold crushing strength of the fired samples at $1400^{\circ} \mathrm{C}$ before and after subsequent 30 cycle thermal shock.

$\left.\mathrm{cm}^{3}\right),{ }^{15)}$ at the expense of $\mathrm{SiC}\left(3.21 \mathrm{~g} / \mathrm{cm}^{3}\right)^{16)}$ of relatively lower density. Therefore, this outcome can be rationalized by the formation of the mullite phase with increasing the temperature and increasing its concentration due to increasing the reaction of the active silica fume with bauxite and the silicate bonding of the waste as indicated in XRD patterns. Increasing of the mullite phase content changed it to be the matrix instead of $\mathrm{SiC}$. This, in turn, lead to well distribution for the $\mathrm{SiC}$ grains and their high compaction by mullite bonding as shown in Fig. 5.

The cold crushing strength of these batches before and after subsequent subjecting to the thermal shocks $(30$ cycles at $950^{\circ} \mathrm{C}$ /water quenching) is shown in Fig. 9. No spalling was observed up to 30 cycles. This was considered to be due to the softening nature (thermo elastic behavior) of aluminosilicate phase, in particularly mullite phase of low thermal expansion coefficient, at high temperatures. ${ }^{14)}$ It is seen that the cold crushing strength before and after the thermal shocking increases with increasing the amount of added bauxite-silica fume mixture of constant ratio $(4: 1)$ at $1400^{\circ} \mathrm{C}$. The increasing in their mechanical strength can be rationalized by high compaction of the mullite phase formed and its homogeneity in the microstructure as previously described. The enhancement in the thermal properties may be due to high thermal shock resistant of $\mathrm{SiC}$ and the formation of the low thermal expansion coefficient mullite phase. The formation of valuable characteristics of the mullite phase, as its chemical stability and compatibility, as matrix for $\mathrm{SiC}$ will decrease the oxidation rate of $\mathrm{SiC}$. The revealed fibrous phases in the microstructure after thermal shocks confirms that the presences of thermoelastic phases such as $\left(\mathrm{SiC}\right.$ and $\left.3 \mathrm{Al}_{2} \mathrm{O}_{3} \cdot 2 \mathrm{SiO}_{2}\right)$. If there is no thermo elastic behavior for the formed phases, the microstructure will be considered to reveal cracks and not fibrous structure.

The ratio of the strengths after 30 subsequent thermal shock cycles and before the shocks increases with increasing mullite concentration up to about $40 \%$. This indicates to improvement of the thermal shock resistance of the samples with increasing the mullite content. This can be understood from the reported datas that thermal shock resistance parameter $(R)$ increases if the phases constitute the structure of the object have low thermal expansion coefficient $(\alpha)$ and Young's modulus $(E)$ or high thermal stress $\left(\sigma_{\mathrm{th}}\right)^{1}$. The $R$ value of mullite $\left(1273^{\circ} \mathrm{C}\right)$ is high compared with value of $\operatorname{SiC}\left(503^{\circ} \mathrm{C}\right)$. In this sense, increasing of mullite content enhances the thermal shock resistance (TSR) as shown in the figure. On the other hand, the thermal stress, which is generated during the thermal cycles, is effectively absorbed by the porosity, so preventing catastrophic crack propagation. In addition, the generation of fine intergranular cracks due to extremely anisotropic thermal expansion properties of the structure phase during the subsequent thermal shock cycles absorbs the strain energy during the cycles, consequently, it enhances TSR. Accordingly, the enhancement of TSR of batches with increasing the content of low thermal expansion coefficient and high $R$ value of in-situ mullite formed and the presence of pores and decreasing of the $\mathrm{SiC}$ content of low $R$ value can be explained in these sense. Microstructure of the samples after 30 subsequent thermal shock cycle, Fig. 4 showed fine fibrous mullite and the presence of pores. This, in turn, absorb the thermal stress and enhances TSR. However, the remarkable decreases of the ratio of the strengths revealed with $50 \%$ bauxite and silica fume addition can explained in the term of the difference in the expansion of mullite and $\mathrm{SiC}$. This means that $30-40 \%$ bauxite and silica fume addition is considered the best concentrations from the thermal shock resistance term.

Finally, the increasing of in-situ mullite formation up in the range of 30-40\% in recycled $\mathrm{SiC}$ waste slab due to the addition of bauxite and silica fumes, are sharing in enhancing the thermal shock resistance and mechanical strength. The thermal shock resistance reaches up to more than 30 cycles for silicon carbide briquettes, and the compressive strength reaches to $770 \mathrm{~kg} / \mathrm{cm}^{2}$ at $40 \%$ silicon carbide slab material and $40 \%$ bauxite and silica fume. After 30 cycles of shocking, the compressive strength was still good and reaches up to $676 \mathrm{~kg} / \mathrm{cm}^{2}$. We think that these obtained specification can be nominate these products for metallurgical and ceramic industries.

\section{Conclusions}

It can be concluded from the results that:

(1) The densifications of the batches as well as their mechanical and thermal properties enhances with the formation of mullite phase and its content. The formation of in-situ mullite was accompanied with serious changes in the microstructures, these changes are responsible for enhancing the mechanical strength and thermal shock resistance.

(2) There are a possibility for recycle and reuse of the SiC slabs waste in manufacturing of SiC-mullite. It is well known that the important specification of ceramic and metallurgical furnaces is resistance for the oxidizing atmosphere, high 
mechanical strength and high thermal shock resistant. Therefore, we can nominate, according to these results, the products include $30-40 \%$ from bauxite/silica fume ratio for these applications.

\section{References}

1) Achari, S. and Satapathy, L. N., Am. Ceram. Soc. Bull., Vol. 82, pp. 1-6 (2003).

2) Budinkove, P. P., "The Technology of Ceramic and Refractories," Ed. by Massachusetts Institute of Technology, Cambridge, Massachusetts (1964).

3) Sivov, V. P., Glass and Ceramics, Vol. 58, pp. 322-325 (2001).

4) Eschenberg, R., Keyk, W., Klages, G., Kowalski, W. and Smeets, L., Interceram, Special Issue, pp. 19-24 (1983).

5) Kaufman, J. W., Campos-Loriz, D., Selkregg, K. R. and Holmes, T. R., Interceram, Special Issue, pp. 48-55 (1983).

6) Kramss, J., Proceedings of International Symposium on Refractories: Refractory Raw Materials \& High Temperature Performance Refractory Products, August (1988) pp. 397-410.

7) Brown, R. W., Proceedings of International Symposium on Refractories: Refractory Raw Materials \& High Temperature
Performance Refractory Products, August (1988) pp. 411-426.

8) Crudu, I., Ion-Scu, M., Munteanu, V., Sandu, I. and Nedelcu, P., Wear, Vol. 216, pp. 251-261 (1998).

9) Rüther, P., "Refractory Materials in Blast Furnace Plants," Verlag Schmid GMBH, http://www.ceramic-journals.com/ english/objekte/cn/cn99_1php.

10) McNally, R., Roulet, F., Kuster, D., Schoennahl, J. and Lucke, D., Refractories Eng., Vol. 3, pp. 2-11 (2002).

11) Bachhofen, H. J., Kowalski, W., Peters, M. and Rüther, P., I \& SM, Vol. 6, pp. 39-45 (1999).

12) Lee, W. E. and Moore, R. E., J. Am. Ceram. Soc., Vol. 81, pp. 1385-1410 (1998).

13) Shibin, L., Zhenlin, L., Jiqiang, G. and Zhihao, J., Mater. Chem. and Phys., Vol. 78, pp. 655-659 (2003).

14) Reddy, N. K., Mater. Chem. and Phys., Vol. 76, pp. 78-81 (2002).

15) Chesters, J. H., "Refractories, Production and Properties," The Iron and Steel Institute, London (1973) pp. 272-272.

16) Reed, J. S., "Principles of Ceramic Processing," John Wiley \& Sons Inc. (1995) pp. 641-642. 